\title{
Tamás Bali
}

\section{Questions on the Hungarian Helicopter Force Transformation}

For more than a half a century, the Hungarian Defence Forces have been using helicopters designed and built in the former Soviet Union. Naturally, operators have gained a lot of experience over the decades, but the whole system has also anchored the pilot training system and maintenance method. Now that the government has decided to procure new western designed helicopters, all of these must be left behind. The Hungarian operators need to learn that new operating philosophy which will definitely pose many challenges toward the pilots and maintainers. In this study, I would like to point out these challenges.

Keywords: helicopter, helicopter force, pilot, transformation, maintenance

\section{Introduction}

It has been 69 years since the Hungarian Defence Forces have been using rotary-winged air assets to support mainly the land forces' operations and related trainings. Apart from the home defence tasks related to land force, helicopters have been utilised to provide search and rescue capability both for the Air force and - in line with the International Civil Aviation Organization Chicago Convention Annex 12 [1] - for the private and commercial actors of the civilian air traffic.

Having been a post Warsaw Pact ${ }^{1}$ country, Hungary has had many products of a former Soviet helicopter design bureau, from the Mi-1 light utility-, to the Mi-24 attack helicopters. This year, we commemorate the $50^{\text {th }}$ anniversary of the Mi- 8 transport helicopters in our service. Even though we plan to fly with our Russian RW assets a few more years, we must admit that the helicopter force is ripe for change.

Former Defence Minister István Simicskó announced the defence and military forces development programme called Zrínyi 2026 on 22 December 2016, in which he aimed to place

\footnotetext{
The Warsaw Pact, formally known as the Treaty of Friendship, Cooperation and Mutual Assistance, was a collective defence treaty signed in Warsaw (Poland) among the Soviet Union and seven Soviet satellite states of Central and Eastern Europe in May 1955, during the Cold War. The Warsaw Pact was the military complement to the Council for Mutual Economic Assistance, the regional economic organisation for the socialist states of Central and Eastern Europe. The Warsaw Pact was created in reaction to the integration of West Germany into NATO in 1955 per the London and Paris Conferences of 1954, but it is also considered that it was motivated by Soviet desires to maintain control over military forces in Central and Eastern Europe. The Warsaw Pact was established as a balance of power or counterweight to NATO [2].
} 
the Hungarian Defence Forces on an upward course by virtue of the availability of additional funds and the implementation of armament developments. Among the plans of this complex programme, there is a reinforcement of the Air force by the procurement of new helicopters. Under the umbrella of Zrínyi 2026 development programme, contracts were signed to implement $20 \mathrm{H} 145 \mathrm{M}$ and $16 \mathrm{H} 225 \mathrm{M}$ helicopters ${ }^{2}$ into the Hungarian military service. These Airbus assets will bring such a new era into the life of the Hungarian helicopter community, which will change the pilot attitude to flying and even the whole maintenance philosophy.

It is not going to be a new phenomenon at the Air force, since its fixed-winged force transformation has started in 2006 with the lease of the Jas-39 Gripens and the procurement of the Airbus A319s and Falcon 7Xs, but a giant leap for the helicopter arm. Now, we are facing a definitely challenging period to convert our pilot training and maintenance methodology to meet the expectation to create a modern and powerful force.

\section{RW Pilot Skill Transformation}

Writing this section, I plan to represent some of the challenges, which are ahead of our helicopter pilots. These are basically because of the technical limitations of our old Russian helicopters and inherited RW deployment philosophy and related training methods.

During the Cold war era, quantity came into view against quality. This does not mean that we were not trained sufficiently, it was only a matter of tactics, technics and procedures.

Undoubtedly, the Soviet Union won World War II with the use of their heavy artillery and ample infantry. The cooperation of these arms could destroy even the strongest enemy. The tactics they used is built on the theory called "Deep operation" developed by Vladimir Kiriakovitch Triandafillov ${ }^{3}$ during the 1920s and 1930s. The maintenance of the offensive, the increase of tempo in the conduct of combat, the use of overwhelming firepower and penetration into the depth of enemy territory became the core premises of the Soviet military philosophy. According to the theory, the infantry is working with heavy artillery to break through the enemy's possibly fortified forward positions, thus allowing the mobile troops to exploit the breach to penetrate the enemy's defensive positions and destroy rear support and service units and ultimately lines of communication. It is necessary to emphasise that destroying, suppressing or disorganising enemy forces must be carried out not only at the line of contact, but throughout the depth of the battlefield [3].

Being confident with the effectiveness of this tactics, the Soviets built all of their RW training syllabus in the post-war era onto this manoeuvre- and mobility-wise theory. But what is needed to grant high mobility and manoeuvrability for such an enormous force? It is unquestionably the number of the helicopters capable of participating in the combatant activities. They created a helicopter training manual, which reflected a step-by-step training method from that of a co-pilot to the main goal of a multi-ship training. Since these training methods were forced to be implemented in the armies of the Warsaw Pact allied nations,

2 The contracts were signed for H145M on 29 June 2018 and for H225M on 17 December 2018.

3 Vladimir Kiriakovitch Triandafillov (14 March 1894 - 12 July 1931) was a Soviet military commander and theoretician. Vladimir Triandafillov was the author of two fundamental military doctrine works: Scale of the Operations of Modern Armies, published in 1926 and Characteristics of the Operations of the Modern Armies, published in 1929. In these two works, he elaborated his deep operations theory about the future warfare. 
it is also echoed in our (and still recent) training manual [4]. As a result of our training, the Hungarian RW assets were supposed to be used at least on squadron, but preferably on wing level (flight formation of a wing!).

The disadvantage of this multi-ship operation method with around 30 helicopters included was that self-defence became a low-priority issue. Due to the high numbers, everybody and everything became replaceable.

For this very reason, the soviet helicopter designers did not plan, for example, any active or passive self-defence systems to be installed onto the transport helicopters. Only the attack helicopters (considering the Mi-24 versions) had the EVU-type heat dissipater as a passive, ACO-2V flare and COEP-V1A infra-jammer as an active defence device. As a self-defence strategy, only evasive manoeuvring remained for our community.

It was an identical situation in 2006, when the Jas-39 Gripens got into our service as a replacement of the $\mathrm{MiG}-29 \mathrm{~s}$. At that time, our fighter pilots were trained to accomplish dogfights, while the modern fighter tactics were built on highly sensitive radars and long-range missiles. Although our pilots were perfectly trained, they could not get involved in any combatant activity, due to the technical and related training limitations.

However, the recent RW warfare focuses on two- or maximum four-ship air raids, where using sophisticated weaponry and self-defence devices alongside are the musts; now we are in the position to carry out extensive multi-ship RW operations, but we do not have the knowledge and experience on self-defence. Considering the human factor, we have to improve on these fields in order to successfully fulfil RW force transformation in the future.

Another challenge is to transform our instrument flight rules (hereinafter: IFR) proficiencies. Let me draw again a historic picture on the Russian way of thinking on IFR flights. The focal point in the theory is: There is no possibility to station fix markers on the hostile operational area. It is impossible due to the high threat level, moreover, it is useless since the force is advancing. If there is a need to support IFR flight, a single mobile non-directional beacon (hereinafter: NDB) must periodically serve it. The focus is on the flights under degraded visual conditions. Evidently, the Hungarian IFR flight training, all of our IFR approach procedures were designed to use only one $\mathrm{NDB}^{4}$ [4].

If we strictly assess the present conditions of asymmetric warfare, we cannot speak more about advancing and retreating forces. Nowadays, the forces are stationed on Forward Operating Bases (hereinafter: FOB) and are deployed in the vicinity of each other. These strongholds are well defended, so there are possibilities to set VHF Omni-Directional Range/ Instrument Landing System (hereinafter: VOR/ILS) IFR navigation aids in their perimeter.

Although I personally believe, that helicopters are not effective war-tools under instrument meteorological conditions, and they should not be flown IFR but DVE, I have to accept that - as an emergency procedure - our pilots must be trained to use VOR/ILS systems. From my point of view, it is an emergency since it is not normal to have a helicopter flying a standard IFR approach relatively low and slow under ground-to-air threat. The training is only needed to an extent to support a landing when a helicopter accidently gets into a cloud while flying DVE. Anyway, since there is a serious disparity between our recent IFR flying skill and the

$4 \quad$ There are inner and outer markers, but the whole procedure is designed to use only the inner marker. The outer one is to provide supplementary information to facilitate a more punctual flight. 
requested one, we also have to work hard to accomplish the RW force transformation on this field.

However, will the Hungarian helicopter pilot community be capable for such a transformation? The answer is: probably not everybody. The reason behind is the age structure of the active RW pilots (Figure 1) and the air assets they were selected and trained for.

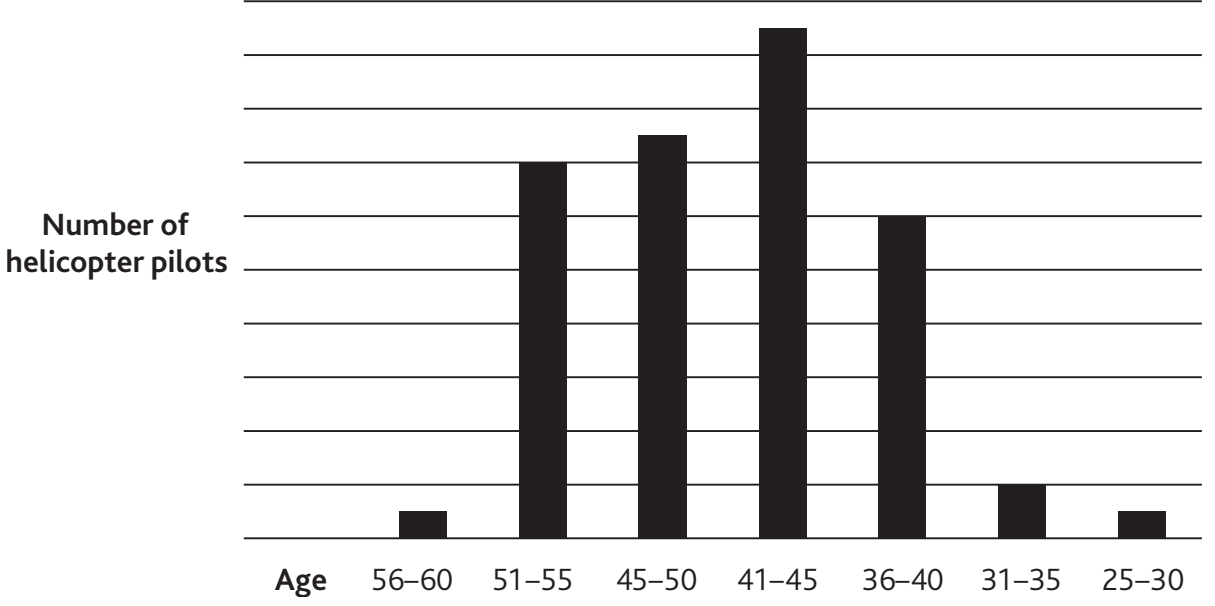

Figure 1

Age structure of the HDF 86, Szolnok Helicopter Base [compiled by the author]

Assessing the shape of the diagram, it becomes clear, that due to the 20 years long institutional training gap, the Hungarian helicopter pilot community is aged. Most of the pilots are older than 40. More than half of them are older than 45, and there is more $50+$ and older than younger of 40 . These numbers imply, that - with a few exception - the given pilots are not computer geeks. But, why is it a problem? Because flying a new generation helicopter (like $\mathrm{H} 145 \mathrm{M}$ and H225M) requires more of a system operator skill than a real pilotage.

When the presently active helicopter pilots were selected and trained, the priority was on the pilotage. The helicopters, which were used to train them (Mi-2, Mi-8, Mi-24) were analogue ones, without any digitalisation and automatisation. Actually, so they are now. It is a big question ahead of the RW force transformation how a relatively old community will cope with the digital era.

Another challenge will be to prepare our co-pilots to meet the modern era requirements. At this point, let me turn back again to the Soviet inheritance. Based on the Soviet method, all the helicopter pilots who complete the institutional RW training are starting as co-pilots. To advance from this position, to become a pilot in command, a person must prove his professional (theoretical and flying) skills, which can positively distinguish him from the others. Only the best co-pilots can be promoted to a higher position. So is the case with the instructor pilot selection. Only the best pilots in command can be promoted to be instructors [4]. It is a kind of a continuous competition amongst the pilots. At first glance it looks like a good system, but truly it is not. It bores friction amongst the pilots, kills the good personal relationship 
amongst the former friends and crew resource management becomes a difficult task (since it is literally an unknown phenomenon).

If we turn back to the basic problem, we can easily define the problem with the co-pilots, which actually does not refer to a fault of theirs, but to the above mentioned training method. According to the Soviet training ideology, only the pilots-in-command and higher pilot categories must have pilot skills, the co-pilots just up to a certain level.

In case of a pilot-in-command's disability of flying, ${ }^{5}$ it becomes the co-pilots responsibility to fly to the nearest landing zone, carry out an approach and land safely (without having the helicopter crashed) under instrument and visual meteorological conditions. Since the real requirement concerning this pilot category is to be capable for VFR and IFR navigation and proper radio-communication, their training focuses decisively on these skills, not on pilotage. As for this, they only have a limited flying hour.

It is also not a secret, that in many cases, there are situations when a quick decision must be made by the (acting) pilot-in-command. Since co-pilots almost never get into this kind of a situation, they do not have to bear the burden of the consequences of a decision, they are not even trained for it. Having these co-pilots without real pilot training and the experience of making decisions on board, their aptitude to the Hungarian RW force transformation is a big question ahead of us.

And a last remark to this topic: There is no guarantee at all that a relatively old, good flying pilot-in-command presently in service will be capable to pass the conversion training's requirements. It can easily happen that a younger co-pilot presently in service, who is a computer geek, will perform much better than a PIC.

\section{Maintainers' Skill Transformation}

Putting western type helicopters into the Hungarian Defence Force's service will bring unavoidably a new maintenance philosophy, which also will set new requirements toward our maintainers. Technology transformation will inevitably lead to a new system-thinking. The debut of a new technology at the HDF's also requests a re-thinking of our education and training schemes both in structure and in content, so that the new generation of maintainers can acquire the necessary professional skills. The transformation raises many challenges and questions as follows.

Recently, due to the complexity of the maintenance tasks to be completed, there must be a specialisation implemented amongst the airframe, engine, radio and navigational systems, electrical- and weapon systems. There are three types of an airworthiness inspection carried out on the Russian designed helicopters on a normal flying day. These are the pre-, intermediate and post-flight inspections. At each of those, seven maintainers go to the helicopter. Four NCOs (with an engine, airframe, radio + navigation and electric system specialisation) do the maintenance works and sign those in the A/C logbook. Two OFs (with an engine + airframe, radio + electric system specialisation) are there to check (inspect) the quality of the work

5 This situation can occur, when a pilot-in-command suddenly becomes unable to fly further due to an external violent influence, which causes body injury, fainting. 
done by the NCOs and they also sign their checks in the logbook. The seventh person who goes to the helicopter is a high ranked engineer with an engine + airframe specialisation.

$\mathrm{He}$ is responsible for the certification of tasks and inspections done by the NCOs and OFs. Nevertheless, after his signature in the A/C logbook, the engineer bears all the responsibility for the maintenance works done; while he checks around the helicopter, the OFs are sauntering around proving no trust.

This distrustful behaviour is also inherited from the Russian era and institutionalised in the recent Maintenance manual [5]. It is not going to happen in the future. According to the Airbus maintenance philosophy, just the pre- and post-flight checks and works must be completed by authorised maintainers. The intermediate inspection (which is just a bit more than refuelling) is the responsibility of the pilot (Figure 2).

\begin{tabular}{|c|c|}
\hline $\begin{array}{l}\text { Pre-, intermediate and postflight } \\
\text { inspections require } 7 \text { maintainers. }\end{array}$ & $\begin{array}{l}\mathbf{I} \\
\mathbf{I} \\
\mathbf{I}\end{array}$ \\
\hline & Pre- and postflight \\
\hline $\begin{array}{c}4 \text { NCOs do the inspections/works } \\
\text { and sign into the A/C Logbook } \\
2 \text { OF maintainers check the } \\
\text { quality of work done by the NCOs } \\
\text { and sign into the A/C Logbook } \\
+ \\
1 \text { Engineer certifies the tasks, } \\
\text { inspections done by the NCOs } \\
\text { and OFs. }\end{array}$ & $\begin{array}{c}\text { inspections require } 2 \\
\text { maintainers } \\
\text { inspection/refuelling } \\
\text { is done by } 1 \text { pilot }\end{array}$ \\
\hline
\end{tabular}

Figure 2

Maintenance work transformation (left: recent, right: future method) [compiled by the author]

In connection with this topic, let me mention a language related challenge which will definitely confine the smooth transition to the western technology.

If we assess the age tree of our maintainers, we can clearly see that the average of them is more than 45 years old. This means that they were definitely trained using Russian not English. Additionally, since all helicopter documentation is written in Russian, they have not really been forced to learn English on a professional level. If we consider transforming these persons into English speakers (since all the documentation will be in English) when we will have the H145M in service in October 2019, that will raise big questions. Recently, there is a training program, which focuses on this problem, where the teaching priority is on the maintainer's language proficiency, but it seems a bit late for them to catch up. The situation is worsened by the fact that the attrition rate is quite high, since there is a maintainer shortage also in private life, where the salary is much higher than in the military. The individuals remaining in the system do not have sufficient time for learning, since they also have to do their professional job. They cannot even maintain their English knowledge. With their confined language proficiency, they do not want to participate in a foreign conversion training concerning western helicopters. Also, they do not want to sign long term contracts 
with harsh conditions (for example: money payback upon failure on examinations which can easily happen due to their language difficulties).

As for the Russian fleet management: Since each of the components of the helicopter was designed to bear at least $50 \%$ more than it is stated as the maximum limitation in the manuals, we can say that the Russian RW assets are really permissive. Even though the Russians have been issuing bulletins, the domestic fleet sustainer decided not to buy those.

This "liberal" way of operation led to the situation, where the Hungarian maintainers, who were supposed to instruct their Afghan colleagues during the ISAF and Resolute Support Missions were helped out by the American and Russian maintainers who were also there to run the helicopters. Obviously, it is not going to happen with the western helicopters, where updating the manuals will not be an option any more. We have to get rid of this engrained pattern of thinking, which will not be easy since the system will be run by the same human resources.

\section{RW Technology and Related Logistic and Infrastructure Transformation}

Each of the modern helicopters are equipped with a modern digital glass cockpit, which is night vision-goggle compatible. This differs from the analogue RW assets that we mainly use in our service (Figure 3.).

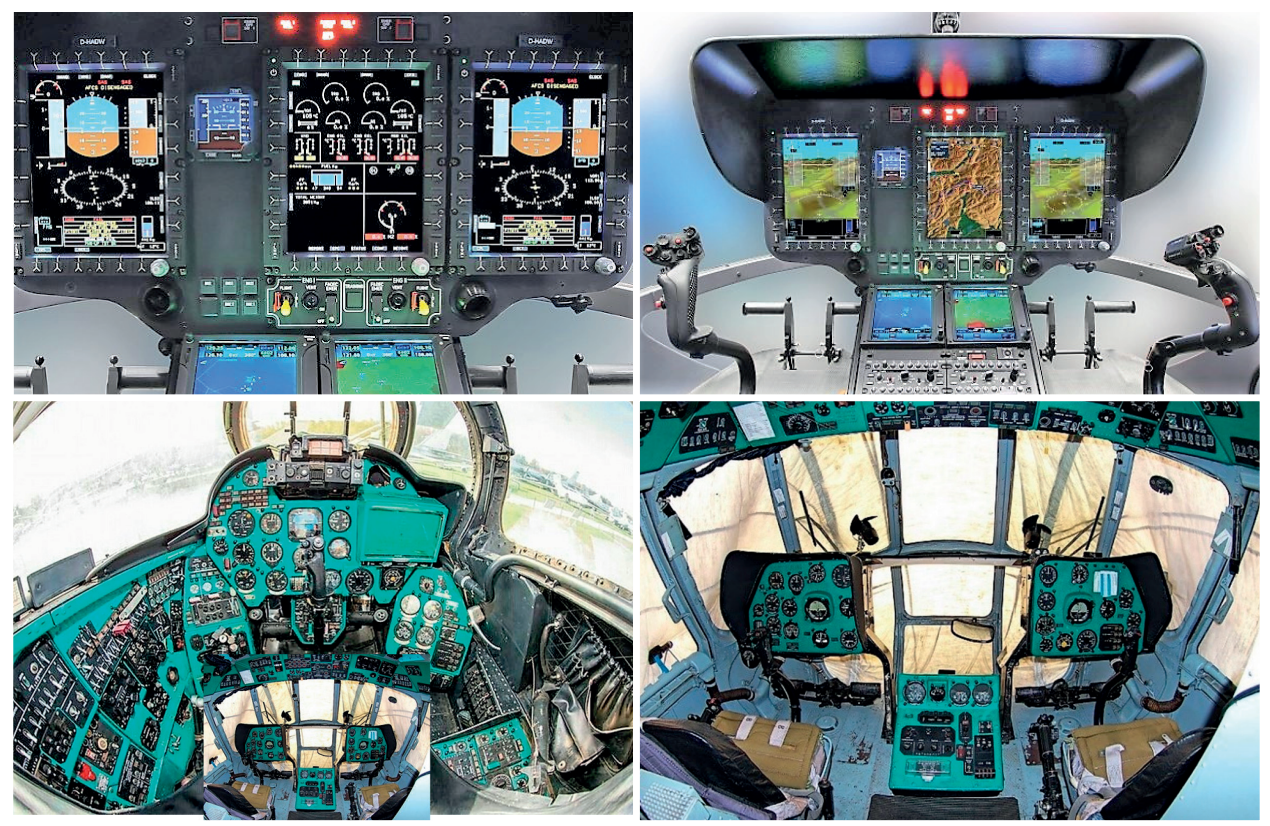

Figure 3.

H145M cockpit (up-right) [7], H145M cockpit (up-left) [8], Mi-24 cockpit (bottom-left) [9], Mi-17 cockpit (bottom-right) [10] 
It is unquestionable, that there is an enormous difference between the cockpit layouts, which represent the level of the technology, when these helicopters were designed.

As long as the analogue era proved its reliability on a low level of expectations, digitalisation reduces drastically the workload of the pilots (for example with the 4-axis digital autopilot) and provides a much better understanding of the operational environment. But, on the other hand, using computers on board raises the sensitivity of the whole system to the outer (mostly meteorological) effects.

Since we have been using old analogue but durable helicopters, we are not used to these sensitivities. As it was not a manufacturer requirement, we have not stored our helicopters in hangars. Without having the need for hangars for storing, we only have base maintenance hangars. Moreover, one of these base maintenance hangars does not have heating, nor proper electric system inside.

The question of storing spare parts goes along with the previously described ideology. According to the Russian combat philosophy, all the air assets (fixed and rotary-winged) must be capable for operation from any Forward Operating Base, under harsh conditions. If there is no need to place the helicopters into hangars, why should the spare parts be there? The only requirement toward a Russian-like store is, that it must be covered from each side. We are not talking here about humidity or temperature issues, just practically about a place, which has enough space inside. It is a crucial criterion, because it is not the same to have a container or to build an air-conditioned storage for spare parts on one of the FOBs of the operational area (for example in the middle of Afghanistan).

The proper storage is one thing, another issue is to run a computer based spare part ordering system. Nowadays, everything is run on paper (on the so called analytic register). If the unit/operator is short of any spare part, an official request must be sent to the commanding Logistic Directorate (J3) to have the given item ordered through the HDF Logistic Centre from the manufacturer (if there is an effective contract with it). If there is no valid contract to acquire the given spare part, a quite a long procurement process must be completed prior to the ordering through the Logistic Centre. It is always the Logistic Centre who communicates with the spare part provider, which means, that there is no direct link to the manufacturer from the operator level. Once the spare part arrives into the country, it must be transported directly into the HDF Central Storage, where it is registered. Having registered, the spare part now is available for the user. This supply chain is shown on Figure 4.

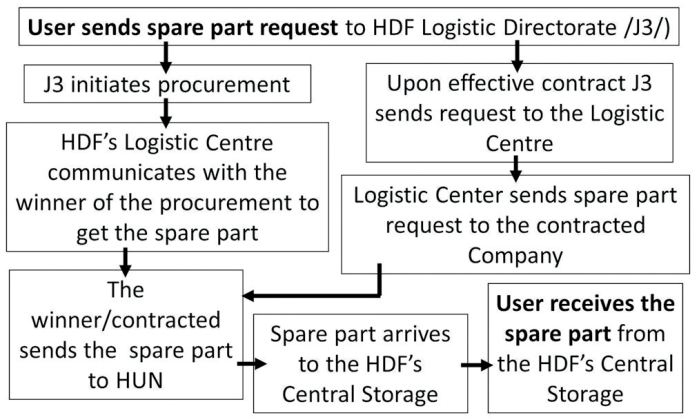

Figure 4

Spare parts supply chain recently used in HDF [compiled by the author] 
If the need arises on the part of the $F O B$, the request is sent to Hungary, and the item is transported to the given location through the Hungarian Defence Force (or allied) logistic supply chain. Without having computers, this bureaucratic, but less vulnerable system slowly but surely works. The case is different with the newly procured helicopters.

Here, the operator communicates in a digitally (computer) supported interactive way directly with the manufacturer (Figure 5). J3 only controls the whole process.

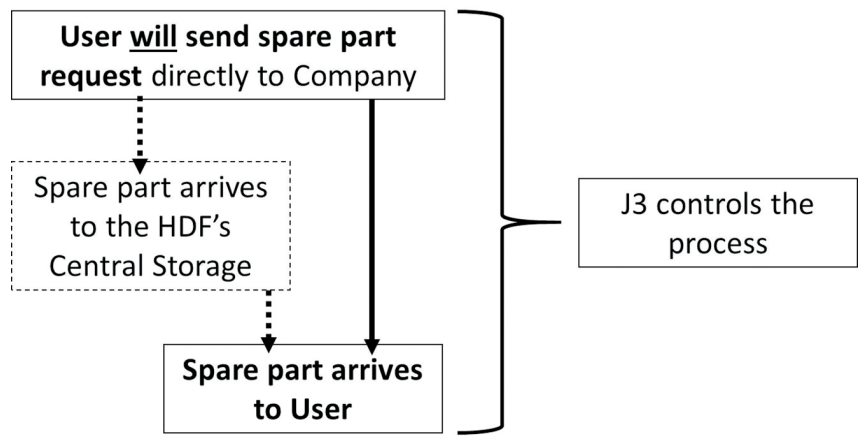

Figure 5 .

Future method to acquire spare parts [compiled by the author]

In this system the responsibility of ordering spare parts will be on the operator, not on the owner anymore, but it puts a big burden on the logistic and/or maintainer expert at unit level that they are not used to. It is quite a big question ahead of the HDF's logistic system how it will cope with this simple-like but complex system.

Furthermore, recently the HDF's logistic system uses a paper-based flight data recording method, periodic maintenance work planning and obsolescence tracking. It is a kind of inheritance from the Soviet era, where simplicity was in the focus. That simplicity, which works everywhere, every time without having even electricity. However, it is not going to be the case in the future, where there is no paper, just a sophisticated software. It is a very quick solution but raises two challenges: 1 . Operating the system puts a great responsibility on the shoulder of the assigned person, which he is not used to (as mentioned above). 2. A PC based, internet supported system must be created even on the FOB. To create and run this system and to build proper storing conditions is a logistic nightmare.

The above described lack of infrastructure and the new concepts of support will definitely pose a big challenge ahead of the smooth force transformation.

\section{Conclusion}

The legacy of having Russian-built helicopters in the service of the Hungarian Defence Force since the 1950s have created a fossilised, paper based and highly bureaucratic maintenance system impregnated by mistrust with crosschecks at every level. Additionally, we inherited such a Soviet training philosophy which carries huge advanced and operational training deficiencies. Apart from these, we have enormous capability deficiencies with regard to our 
helicopters' technology level (aged weaponry, insufficient self-defence and communication systems and no electronic warfare device). The Zrínyi 2026 Force Development program established a solid basis to overcome these problems by procuring new, western designed and built helicopters.

The future will bring challenges for pilots, maintainers and even logistic professionals to transform their knowledge to meet the requirements set by the Airbus, but from the broader perspective, set by the modern expectations of warfare.

\section{REFERENCES}

[1] International Civil Aviation Organization, Annex 12 to the Convention on International Civil Aviation. Search and Rescue. Eighth Edition, July 2004.

[2] Warsaw Pact. Available: https://en.wikipedia.org/wiki/Warsaw_Pact [Accessed Feb. 14, 2019].

[3] Ch. E. Thompson, The Red Army's Failure and the Birth of the Deep Operations Theory of Annihilation. U.S. Army Command and General Staff College, 2017.

[4] Re/1320 Mi-8 Helikopter Harckiképzési Szakutasitás. Honvédelmi Minisztérium, 1981.

[5] Re/415 Magyar Honvédség Repülőmüszaki szabályzat. Magyar Honvédség, 2013.

[6] NATO Standardization Office, AAP-6 NATO Glossary of Terms and Definitions. Brussels-Bel, 2016.

[7] Pinterest, "H145M cockpit," Pinterest, [Online]. Available: www.pinterest.com/pin/83014 0143784101200/ [Accessed Feb. 14, 2019].

[8] Aerokurir, "Cockpit-Innovationen bei Helikoptern," [Online]. Available: www.aerokurier. de/motorflug/franzoesische-evolution-cockpit-innovationen-bei-helikoptern/ [Accessed Feb. 14, 2019].

[9] Pinterest, "Mi-24 cockpit," Pinterest, [Online]. Available: www.pinterest.com/pin/386113 368024517814/ [Accessed Feb. 14, 2019].

[10] Wikipedia, the free encyclopedia, "Mi-17 cockpit," Wikipedia, the free encyclopedia, [Online]. Available: https://en.wikipedia.org/wiki/Mil_Mi-8 [Accessed Feb. 14, 2019].

\section{A MAGYAR HELIKOPTER ERŐK ÁTALAKÍTÁSÁNAK KÉRDÉSEI}

Már több mint egy fél évszázada a Magyar Honvédség olyan helikoptereket használ, amelyek a volt Szovjetunióban lettek tervezve és megépitve. Természetesen az évtizedek alatt nagyon sok tapasztalatot szereztek az üzemeltetők, de ezzel együtt berögzültek pilótaképzési és repülömüszaki kiszolgálási eljárások. Most, hogy új, nyugati helikopterek beszerzéséröl döntött a kormány, mindezeket maguk mögött kell hagyniuk. Újüzemeltetési filozófiát kell elsajátítaniuk, ami sok kihívást hordoz magában. Jelen tanulmányomban ezekre a kihívásokra kívánok rámutatni.

Kulcsszavak:helikopter, helikoptervezető, helikopter erök, átalakítás, kiszolgálás 
Dr. Bali Tamás ezredes

Bázisparancsnok helyettes

MH 86. Szolnok Helikopter Bázis

bali.tamas@hm.gov.hu

https://orcid.org/0000-0001-6098-8602
Col. Tamás Bali, PhD

Deputy Base Commander

HDF 86th Szolnok Helicopter Base

bali.tamas@hm.gov.hu

https://orcid.org/0000-0001-6098-8602

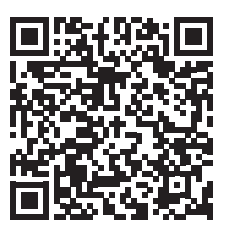

